Part III

\title{
Fantasia of the Future
}


